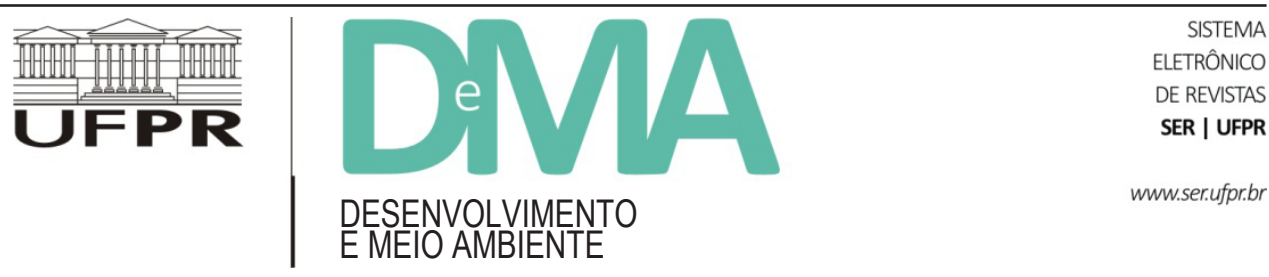

\title{
Depoimento de Carlos Alberto Faraco ${ }^{1}$
}

Lembrando de Magda Zanoni

Agradeço o convite para estar neste evento que celebra os 22 anos do Programa de Pós-Graduação em Meio-Ambiente e Desenvolvimento. Cumprimento a Coordenação, os docentes, os alunos e os funcionários do Programa por estes 22 anos de profícua existência.

Quando estava na Reitoria da UFPR, costumava dizer aos colegas da equipe que, na gestão universitária, a gente semeia, mas não sabe se vai colher. Assim, fico feliz em estar aqui hoje testemunhando que a semente era fértil e que a árvore tem dado muitos e bons frutos.

E, claro, celebrar o aniversário do Programa é também homenagear - in memoriam - a profa. Magda Zanoni, que foi a idealizadora e a maior incentivadora de sua criação.

Magda foi uma incansável batalhadora. Era uma ideia nova criar um espaço acadêmico para a pesquisa em meio-ambiente e desenvolvimento reunindo pesquisadores das áreas sociais e das várias áreas que tratam, em suas especificidades, do meio-ambiente.
O novo, como bem sabemos, costuma provocar resistências e não foi diferente com o projeto deste Programa de Pós-Graduação. Mas elas foram vencidas e ele pôde ir em frente e pôde ser implantado graças principalmente ao esforço incansável de Magda Zanoni. Ela resistiu às resistências; trouxe especialistas franceses; agregou e animou o corpo docente local; e não deu tréguas à administração da Universidade.

Guardo ótimas lembranças da Magda desde nossa primeira conversa. Embora não nos conhecêssemos, ela entrou no gabinete da Reitoria como se fôssemos amigos há longa data e foi apresentando o projeto não como uma proposta a ser ainda discutida e pensada para um futuro remoto, mas como um projeto sobre cuja viabilização não pairava a mínima sombra de dúvida. E foi sempre assim com Magda naqueles primeiros anos deste Programa de Pós-Graduação.

Nas nossas idas e vindas acabamos nos tornando grandes amigos e ainda estive com ela em 1994 quando a UNESCO concedeu à UFPR a Cátedra de Meio-Ambiente e Desenvolvimento, graças, de novo, ao empenho da Magda.

\footnotetext{
${ }^{1}$ Doutor em Linguística, Professor Titular do Departamento de Linguística da UFPR e reitor da UFPR - gestão 1990-94.
} 
Depois deixei a Reitoria e, pelas circunstâncias da vida, não mais me encontrei com ela, mas sempre tive notícias suas - as boas e, infelizmente, também as más - e continuei acompanhando à distância o crescimento do Programa de Pós-Graduação até que meu filho, biólogo de formação e muito exigente academicamente, optou por fazer aqui seu doutoramento. Isso foi, para mim, sinal muito concreto de que o projeto tinha vingado.
Encerro minha intervenção cumprimentando mais uma vez todos os que, nestes 22 anos, tornaram este Programa uma realidade. E, não só como o ex-reitor que viu o Programa nascer, mas principalmente como amigo, reitero minhas homenagens à memória da nossa querida e inesquecível Magda Zanoni. 